\title{
Induction of proteasome expression in skeletal muscle is attenuated by inhibitors of NF- $\kappa$ B activation
}

\author{
SM Wyke', ST Russell' and MJ Tisdale*,I \\ 'Pharmaceutical Sciences Research Institute, Aston University, Birmingham B4 7ET, UK
}

The potential for inhibitors of nuclear factor $-\kappa \mathrm{B}(\mathrm{NF}-\kappa \mathrm{B})$ activation to act as inhibitors of muscle protein degradation in cancer cachexia has been evaluated both in vitro and in vivo. Activation of $\mathrm{NF}-\kappa \mathrm{B}$ is important in the induction of proteasome expression and protein degradation by the tumour factor, proteolysis-inducing factor (PIF), since the cell permeable NF- $\kappa \mathrm{B}$ inhibitor SN50 (I $8 \mu \mathrm{M}$ ) attenuated the expression of $20 \mathrm{~S}$ proteasome $\alpha$-subunits, two subunits of the I9S regulator MSSI and p42, and the ubiquitinconjugating enzyme, $\mathrm{E}_{14 \mathrm{k}}$, as well as the decrease in myosin expression in murine myotubes. To assess the potential therapeutic benefit of NF- $\kappa$ B inhibitors on muscle atrophy in cancer cachexia, two potential inhibitors were employed; curcumin ( $50 \mu \mathrm{M}$ ) and resveratrol $(30 \mu \mathrm{M})$. Both agents completely attenuated total protein degradation in murine myotubes at all concentrations of PIF, and attenuated the PIF-induced increase in expression of the ubiquitin-proteasome proteolytic pathway, as determined by the 'chymotrypsin-like' enzyme activity, proteasome subunits and E2 $14 \mathrm{k}$. However, curcumin ( 150 and $300 \mathrm{mg} \mathrm{kg}^{-1}$ ) was ineffective in preventing weight loss and muscle protein degradation in mice bearing the $\mathrm{MACl} 6$ tumour, whereas resveratrol $\left(1 \mathrm{mg} \mathrm{kg}^{-1}\right.$ ) significantly attenuated weight loss and protein degradation in skeletal muscle, and produced a significant reduction in NF- $\kappa$ B DNAbinding activity. The inactivity of curcumin was probably due to a low bioavailability. These results suggest that agents which inhibit nuclear translocation of NF- $\kappa \mathrm{B}$ may prove useful for the treatment of muscle wasting in cancer cachexia.

British Journal of Cancer (2004) 91, 1742-1750. doi:I0.1038/sj.bjc.6602I65 www.bjcancer.com

Published online 12 October 2004

(C) 2004 Cancer Research UK

Keywords: cancer cachexia; muscle wasting; NF- $\kappa$ B; proteasome expression

Loss of skeletal muscle mass in cancer patients has a negative influence on prognosis, resulting in asthenia, immobility and early death. While lysosomal and calcium-activated proteases play some role in the breakdown of myofibrillar proteins, the ubiquitinproteasome proteolytic pathway is considered to be the predominant system in both experimental models of cancer cachexia (Attaix et al, 1999) and in cancer patients (Bossola et al, 2003). Proteins to be degraded are marked by the covalent attachment of a polyubiquitin chain, which is recognised by the $19 \mathrm{~S}$ subunits of the $26 \mathrm{~S}$ proteasome, a multisubunit cylindrical structure composed of $\alpha$ and $\beta$ units, with the proteolytic enzymes situated on the inner surface of the cylinder on the $\beta$-subunits. Expression of the enzymes of ubiquitin conjugation and proteasome subunits are upregulated in cancer cachexia (Lorite et al, 1998). Knowledge of the mechanism for the regulation of proteasome expression in cancer cachexia should facilitate the design of effective inhibitors.

Muscle mass in cancer cachexia is strongly regulated by a tumour produced sulphated glycoprotein, proteolysis-inducing factor (PIF), which inhibits protein synthesis and stimulates protein degradation (Lorite et al, 1997). The effect on protein degradation is due to an increased gene and protein expression of the key components of the ubiquitin-proteasome proteolytic

*Correspondence: Professor MJ Tisdale; E-mail: m.j.tisdale@aston.ac.uk Received 29 April 2004; revised 4 August 2004; accepted 6 August 2004; published online 12 October 2004 pathway (Lorite et al, 2001). In murine myotubes, induction of proteasome expression by PIF is associated with an increased DNA-binding activity of the transcription factor NF- $\kappa \mathrm{B}$, concomitant with a transient decrease in cytosolic levels of the NF- $\kappa \mathrm{B}$ inhibitor protein, $\mathrm{I}-\kappa \mathrm{B} \alpha$ (Whitehouse and Tisdale, 2003). Degradation of $\mathrm{I}-\kappa \mathrm{B} \alpha$ is initiated by phosphorylation of two serine residues (32 and 36) in the N-terminal portion of the molecule, which results in ubiquitination and subsequent degradation by the $26 \mathrm{~S}$ proteasome (Brockman et al, 1993). Phosphorylation is mediated by a high molecular weight complex (I- $\kappa \mathrm{B}$ kinase or IKK), which in the case of PIF is probably activated by protein kinase C (PKC) (Smith et al, 2004). The polyunsaturated fatty acid, eicosapentaenoic acid (EPA), which has been shown to preserve muscle mass in cancer cachexia by downregulating the increased expression of the ubiquitin-proteasome pathway (Whitehouse et al, 2001), prevented PIF-induced nuclear migration of NF- $\kappa \mathrm{B}$, loss of I- $\kappa \mathrm{B} \alpha$ and the increase in proteasome expression (Whitehouse and Tisdale, 2003). This suggests that agents that interfere with activation of $\mathrm{NF}-\kappa \mathrm{B}$ may be useful in preventing muscle protein degradation in cancer cachexia.

Two potential agents have been studied to verify this hypothesis. Curcumin, a natural product from tumeric, prevents activation of $\mathrm{NF}-\kappa \mathrm{B}$ by blocking phosphorylation and subsequent degradation of $\mathrm{I}-\kappa \mathrm{B} \alpha$ and has been shown to increase the rate and extent of muscle regeneration after trauma (Thaloor et al, 1999). Resveratrol, a natural phytoalexin found in red wine also inhibits NF- $\kappa \mathrm{B}$ 
activation through inhibition of IKK (Holmes-McNary and Baldwin, 2000). Both agents have been evaluated for their ability to inhibit PIF-induced proteasome expression in vitro and as anticachectic agents in mice bearing the MAC16 tumour, which induces profound cachexia involving wasting of skeletal muscle (Beck and Tisdale, 1987).
A

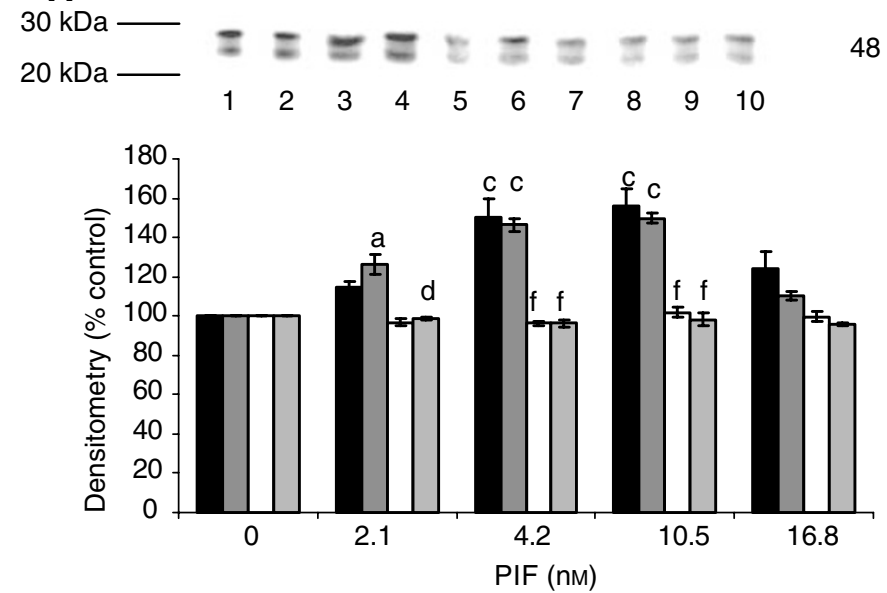

C
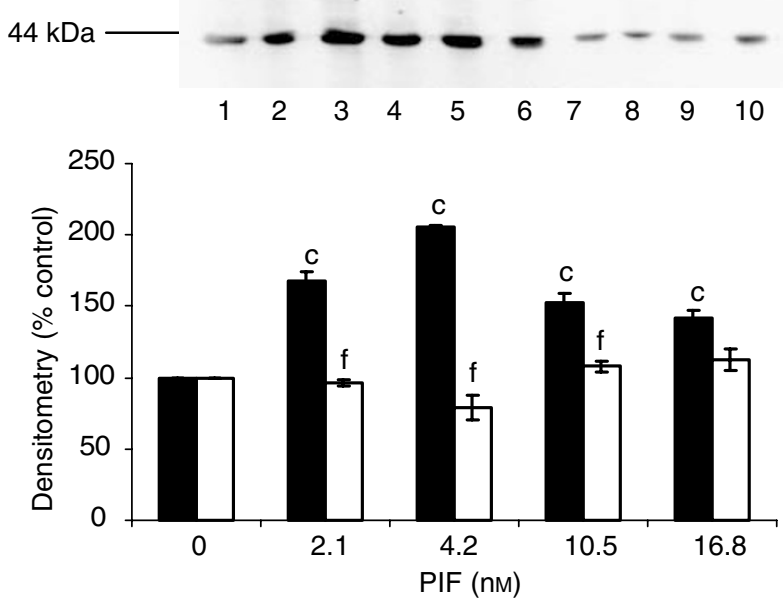

E
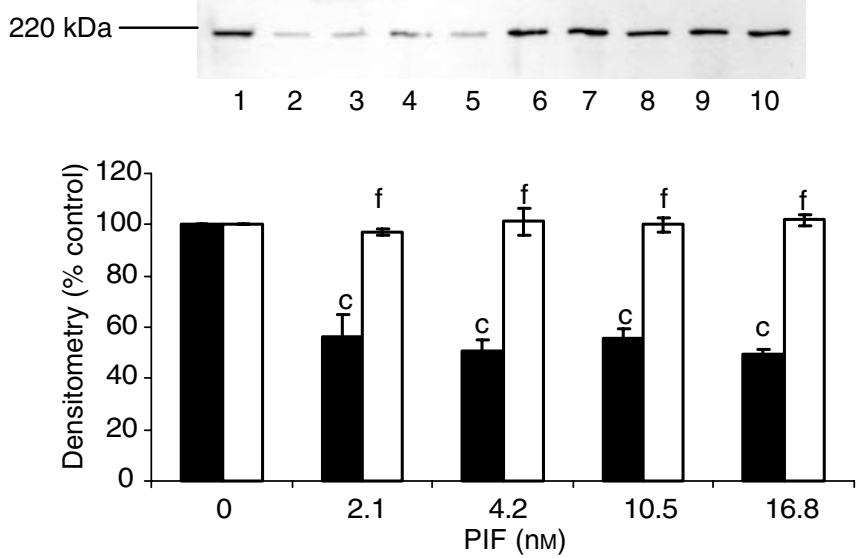

B
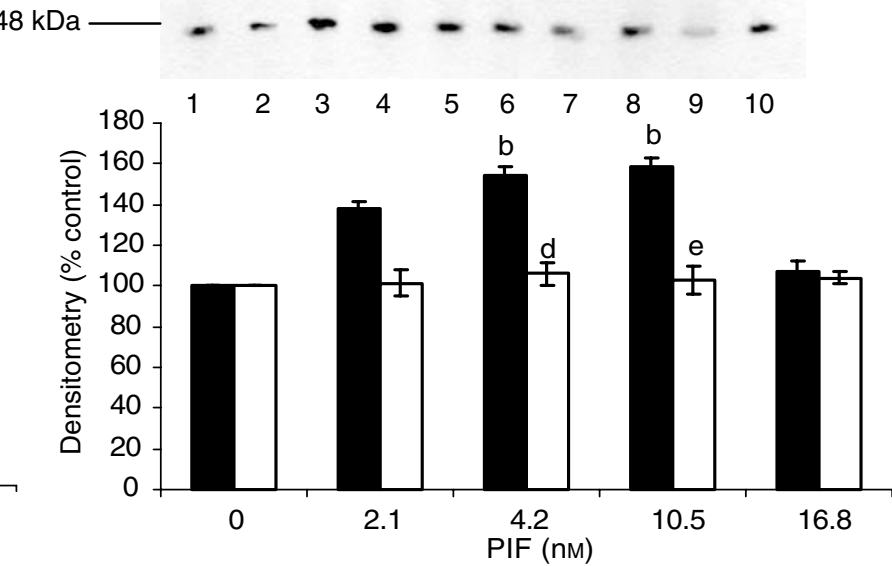

D
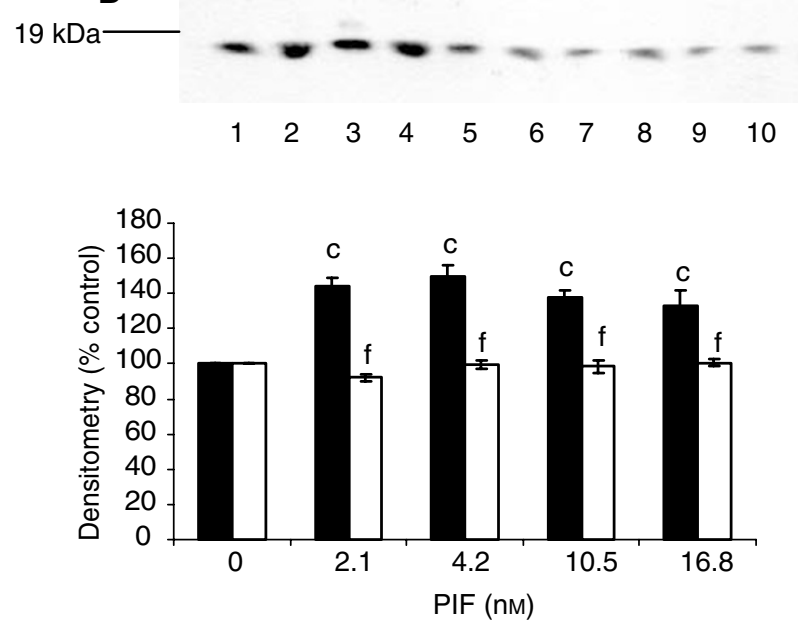

$\mathbf{F}$

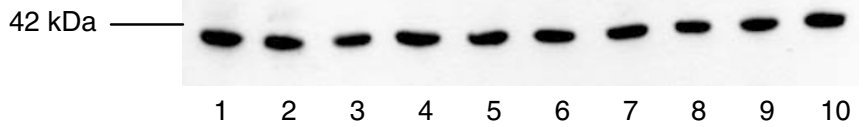

Figure I Effect of SN50 (I $8 \mu \mathrm{M})$ (lanes 6-10) and the cell permeable inactive control peptide SN50M (I $8 \mu \mathrm{M})($ lanes I-5) on PIF-induced expression of $20 \mathrm{~S}$ proteasome $\alpha$-subunits $(\mathbf{A}), \mathrm{MSSI}$ (B), p42 (C), E2 $14 \mathrm{k}(\mathbf{D})$ and myosin $(\mathbf{E})$ in murine myotubes $24 \mathrm{~h}$ after addition of PIF, as determined by Western blotting. The peptides were added $2 \mathrm{~h}$ prior to PIF. An actin loading control is shown in (F). Myotubes were treated with 0 (lanes I and 6), 2.I (lanes 2 and 7), 4.2 (lanes 3 and 8), 10.5 (lanes 4 and 9) and 16.8 nM PIF (lanes 5 and 10). A densitometric analysis presenting the average of three separate blots is shown for each Western blot. The densitometric analysis of the proteasome $20 \mathrm{~S} \alpha$-subunits is for the two major bands in the absence ( $\boldsymbol{\square}, \square)$ and presence ( $\square$, $\square$ ) of SN50 (I $8 \mu \mathrm{M})$. Values for the control peptide are shown as solid boxes and for SN50 as open boxes. Differences from control are indicated as a, $P<0.05$, $b, P<0.01$ and $c, P<0.00$ I, while differences from the control peptide in the presence of SN50 are shown as $d, P<0.05, e, P<0.0$ I and $f, P<0.00$ I. 


\section{MATERIALS AND METHODS}

\section{Animals}

Pure strain male NMRI mice (average weight $25 \mathrm{~g}$ ) were obtained from our own inbred colony and were fed a rat and mouse breeding diet (Special Diet Services, Witham, UK) and water ad libitum. Animals were implanted with the MAC16 tumour s.c. in the flank by means of a trochar, selecting from donor animals with established weight loss (Beck and Tisdale, 1987). Animals with an average weight loss of 5\% (10-12 days after transplantation) were randomised to receive resveratrol $\left(1 \mathrm{mg} \mathrm{kg}^{-1}\right.$ body weight dissolved in DMSO: PBS $(1: 20))$ i.p. daily, while controls received solvent alone. Body weight and tumour volume were measured daily. Tumour volume was calculated from the formula: Length $\times(\text { width })^{2} / 2$. All animal experiments followed a strict protocol, approved by British Home Office, and the ethical guidelines that were followed meet the standards required by the UKCCR guidelines (Workman et al, 1998). Animals were terminated by cervical dislocation and the soleus muscles were
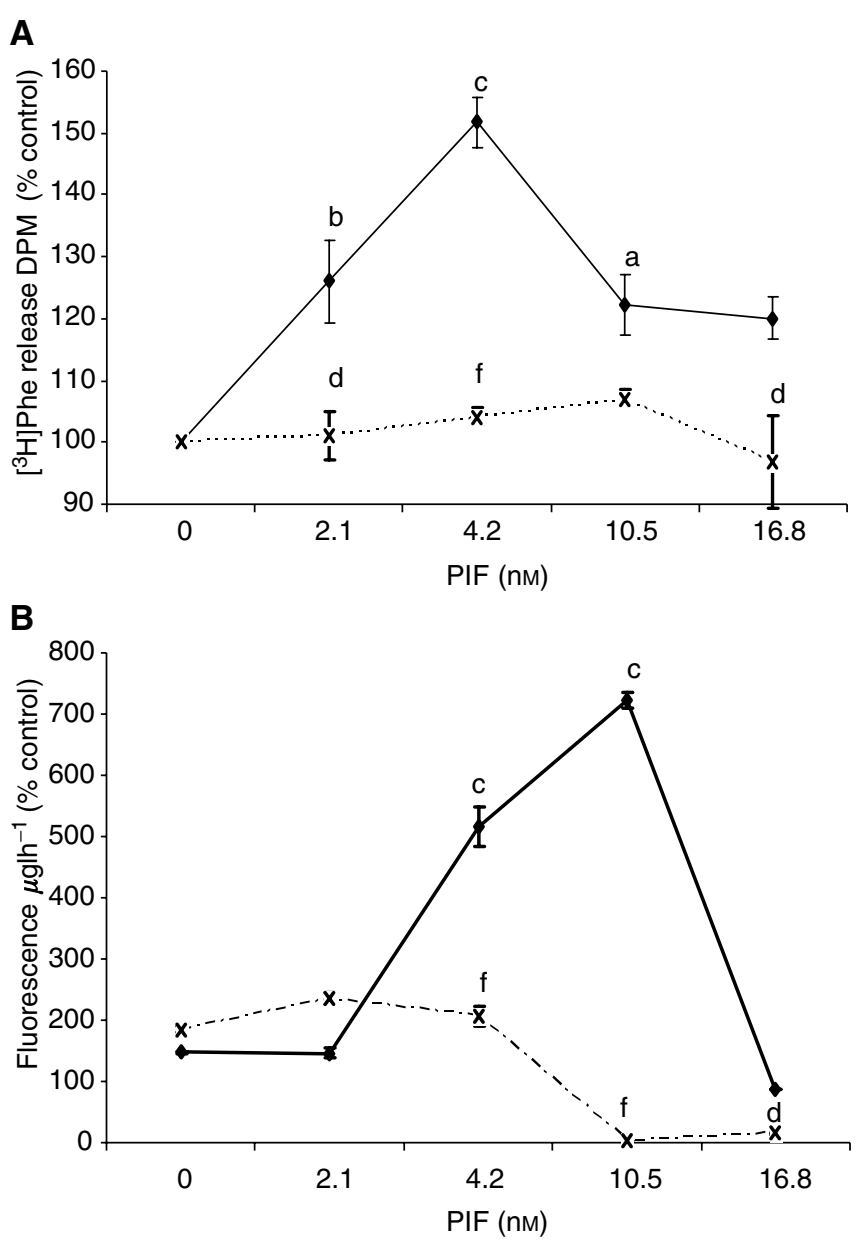

Figure 2 (A) Effect of curcumin $(50 \mu \mathrm{M})$ on total protein degradation in the presence of PIF for $24 \mathrm{~h}$, as measured by the release of $\left[{ }^{3} \mathrm{H}\right]$ phenylalanine. Myotubes were incubated with PIF alone $(\bullet)$ or pretreated with curcumin $(x) 2 \mathrm{~h}$ prior to the addition of PIF. Differences from $0 \mathrm{nM} P \mathrm{PIF}$ are indicated as $b, P<0.0 \mathrm{I}$ and $c, P<0.00 \mathrm{I}$, while differences in the presence of curcumin are indicated as $d, P<0.05$ and $f, P<0.001$. $n=9$. The experiment was repeated three times. (B) Chymotrypsin-like enzyme activity in soluble extracts of murine myotubes after treatment with PIF alone for $24 \mathrm{~h}(\bullet)$, or after treatment with PIF in the presence of curcumin $(x)$. The experiment was repeated three times $(n=9)$. The symbols for the differences are the same as in $(\mathbf{A})$. quickly dissected out, together with intact tendons, and maintained in isotonic ice-cold saline before determination of protein degradation. For protein degradation, muscles were fixed by their tendons at approximately resting length in $3 \mathrm{ml}$ of oxygenated (95\% oxygen:5\% carbon dioxide) Krebs-Henseleit Buffer ( $\mathrm{pH}$ 7.4) containing $5 \mathrm{~mm}$ glucose and $0.5 \mathrm{~mm}$ cycloheximide. The protein degradation rate was determined by the release of tyrosine (Waalkes and Udenfriend, 1957) over a $2 \mathrm{~h}$ period.

\section{Materials}

Foetal calf serum (FCS), horse serum (HS) and Dulbecco's modified Eagle's medium (DMEM) were purchased from Life Technologies (Paisley, UK). Mouse monoclonal antibodies to 20S

\section{A}
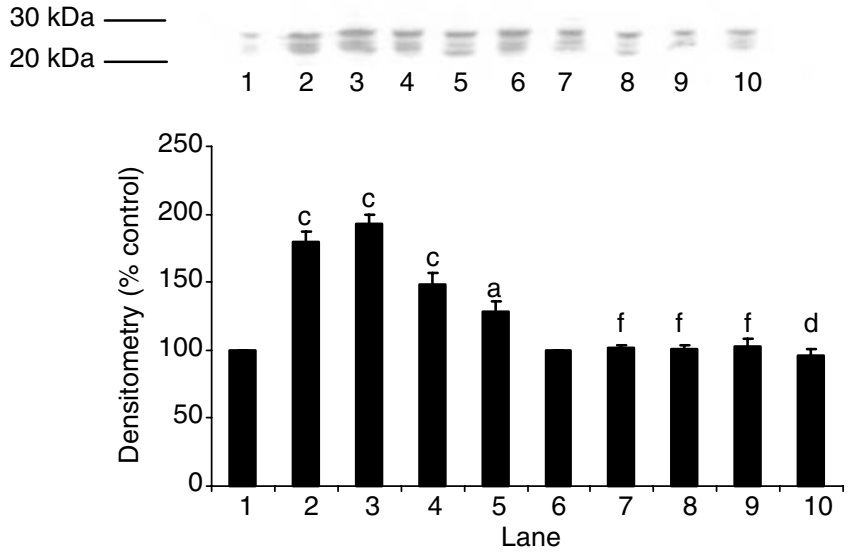

B
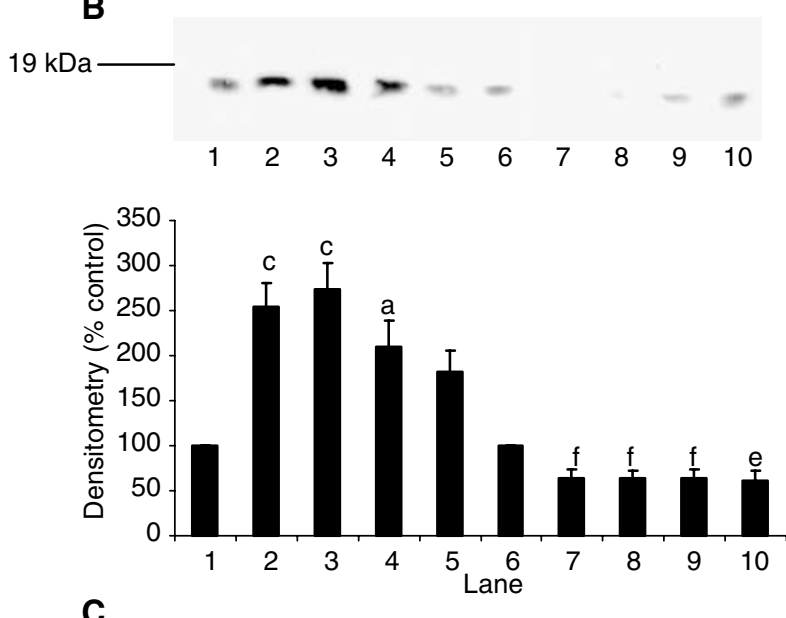

C

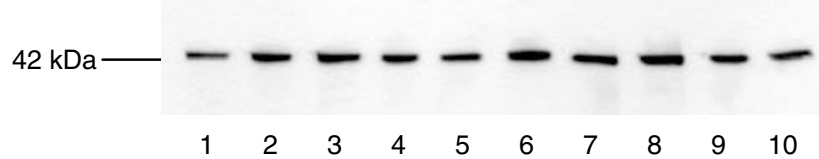

Figure 3 Effect of curcumin on PIF-induced expression of 205 proteasome $\alpha$-subunits $(\mathbf{A})$ and $E 2_{14 k}(\mathbf{B})$ in murine myotubes, determined by Western blotting. Cells were incubated for $24 \mathrm{~h}$ with 0 (lanes I and 6), 2.I (lanes 2 and 7), 4.2 (lanes 3 and 8), I0.5 (lanes 4 and 9) or I6.8 nM PIF (lanes 5 and I0) in the absence (lanes I-5) or presence (lanes 6- I0) of curcumin $(50 \mu \mathrm{M})$ added $2 \mathrm{~h}$ prior to PIF. An actin loading control is shown in (C). Densitometric analysis of three separate blots is shown under each Western blot. Differences from $0 \mathrm{nM}$ PIF are shown as a, $P<0.05, b$, $P<0.01$ and $c, P<0.001$, while differences in the presence of curcumin are indicated as $d, P<0.05, e, P<0.01$ and $f, P<0.001$. 


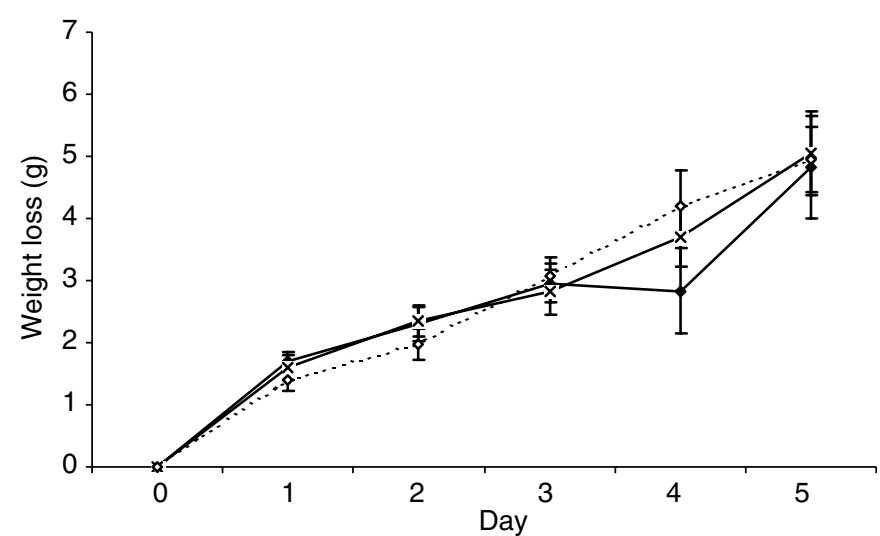

Figure 4 Effect of curcumin administered p.o. daily at I50 $(x)$ or 300 $(\diamond) \mathrm{mg} \mathrm{kg}^{-1}$ in DMSO:PBS (I : I000), as previously used (Busquets et al, 200I), compared with DMSO:PBS (I : I000) alone ( ) on weight loss in mice bearing the MACl 6 tumour over a 5 day period. There was a significant weight loss for all groups at day $5(P<0.00$ I), but there was no difference in weight loss between groups.

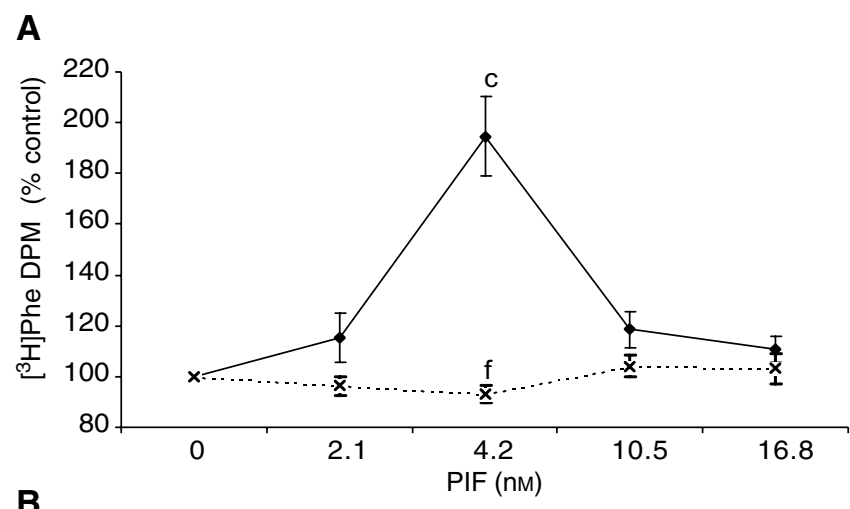

B

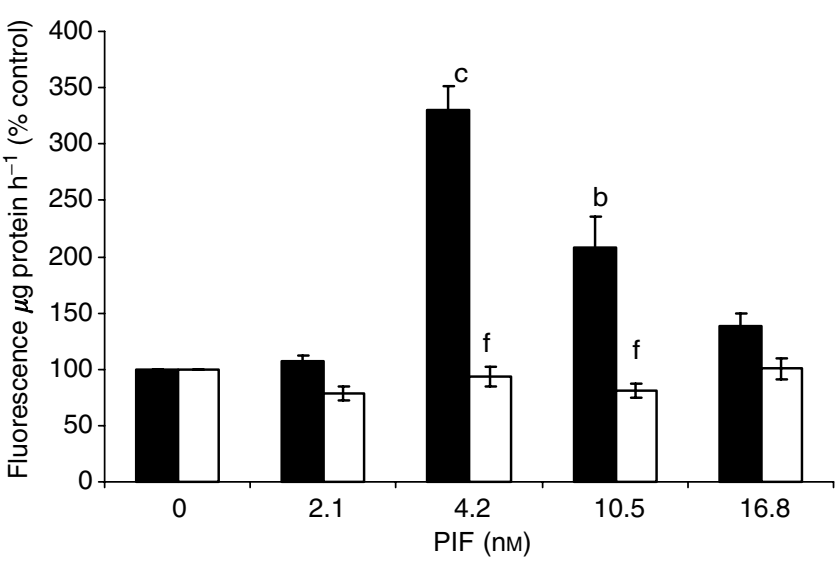

Figure 5 (A) Effect of resveratrol $(30 \mu \mathrm{M})$ on total protein degradation in murine myotubes in the presence of PIF for $24 \mathrm{~h}$, as measured by the release of $\left[{ }^{3} \mathrm{H}\right]$ phenylalanine. Myotubes were incubated with PIF alone $(\bullet$ or preincubated with resveratrol $2 \mathrm{~h}$ prior to addition of PIF and maintained in the culture medium over the $24 \mathrm{~h}$ period $(x)$. Differences from control are indicated as $b, P<0.01$ and $c, P<0.001$, while differences in the presence of resveratrol are indicated as $f, P<0.001$. The experiment was repeated three times $(n=9)$. (B) Chymotrypsin-like enzyme activity in soluble extracts of murine myotubes after treatment with PIF alone for $24 \mathrm{~h}$ (solid boxes) or after treatment with PIF in the presence of resveratrol $(30 \mu \mathrm{M})$ (open boxes). The symbols for the differences are the same as in (A). The experiment was repeated three times $(n=9)$. proteasome $\alpha$-subunits, MSS1 and p42 were purchased from Affiniti Research Products (Exeter, UK), while mouse monoclonal antibody to myosin heavy chain was from Novocastra (Newcastle, $\mathrm{UK}$ ) and to $\mathrm{I}-\kappa \mathrm{B} \alpha$ was from Biomol Research Laboratories Inc. (PA, USA). Rabbit polyclonal antisera to mouse actin was from Sigma Aldridge (Dorset, UK) and to ubiquitin conjugating enzyme $\left(\mathrm{E} 2_{14 \mathrm{k}}\right)$ was a gift from Dr Simon Wing, McGill University, Montreal, Canada. Peroxidase-conjugated rabbit anti-mouse antibody and peroxidase-conjugated goat anti-rabbit antibody were purchased from Dako Ltd. (Cambridge, UK). Hybond A nitrocellulose membranes and enhanced chemiluminescence (ECL) development kits were from Amersham International (Bucks, UK). Electrophoretic-mobility shift (EMSA) gel shift assay kits were from Panomics (California, USA). SN50 and its inactive congener (Lin et al, 1995) were purchased from Calbiochem (Nottingham, UK). Curcumin was purchased from Sigma Aldridge (Dorset, UK), and resveratrol from Biomol Research Laboratories Inc. (PA, USA).

\section{Purification of PIF}

Proteolysis-inducing factor was purified from solid MAC16 tumours excised from mice with a weight loss between 20 and $25 \%$ as previously described (Todorov et al, 1996a; Whitehouse and Tisdale, 2003). Tumours were homogenised in $10 \mathrm{~mm}$ Tris$\mathrm{HCl}, \mathrm{pH} 8.0$, containing $0.5 \mathrm{~mm}$ phenylmethylsulphonyl fluoride, $0.5 \mathrm{mM}$ EGTA and $1 \mathrm{~mm}$ dithiothreitol (DTT) at a concentration of $5 \mathrm{mlg}^{-1}$ tumour. The supernatant obtained after addition of ammonium sulphate $\left(40 \% \mathrm{w} \mathrm{v}^{-1}\right)$ was subjected to affinity chromatography using anti-PIF monoclonal antibody coupled to a solid matrix. The immunogenic fractions were concentrated and used for further studies. The purity of the PIF was confirmed by polyacrylamide gel electrophoresis and immunoblotting. This showed a band for PIF at $M_{\mathrm{r}} 24000$, sometimes accompanied by an albumin-bound band at $M_{\mathrm{r}} 69000$ (Todorov et al, 1996b). No other bands were apparent.

\section{Cell culture}

$\mathrm{C}_{2} \mathrm{C}_{12}$ myoblasts were propagated in DMEM supplemented with $10 \%$ FCS, glutamine and $1 \%$ penicillin-streptomycin under an atmosphere of $10 \% \mathrm{CO}_{2}$ in air at $37^{\circ} \mathrm{C}$. Myotubes were formed by allowing confluent cultures of myoblasts to differentiate in DMEM containing $2 \% \mathrm{HS}$ with medium changes every 2 days. Differentiation was complete in 5-7 days, and the cells remained viable for a further 4-5 days.

\section{Measurement of protein degradation}

This was determined as described previously (Whitehouse and Tisdale, 2003) by prelabelling cells for $24 \mathrm{~h}$ with $\mathrm{L}-\left[2,6^{3} \mathrm{H}\right]$ phenylalanine $\left(0.67 \mathrm{mCi} \mathrm{mmole}^{-1}\right)$ followed by extensive washing in PBS and further incubation for $2 \mathrm{~h}$ in DMEM without phenol red until no more radioactivity appeared in the supernatant. Protein degradation was determined by the release of $\left[2,6^{3} \mathrm{H}\right]$ phenylalanine into the medium after $24 \mathrm{~h}$ in the presence of various concentrations of PIF together with $2 \mathrm{~mm}$ cold phenylalanine to prevent reincorporation of radioactivity in the cells.

\section{Measurement of proteasome activity}

'Chymotrypsin-like' enzyme activity was determined fluorimetrically by the method of Orino et al (1991) by the release of aminomethyl coumarin (AMC) from the fluorogenic peptide succinyl-LLVY-AMC. This method has been described previously for $\mathrm{C}_{2} \mathrm{C}_{12}$ myotubes (Whitehouse and Tisdale, 2003). Activity was measured in the absence and presence of the specific proteasome 
A

$30 \mathrm{kDa}$

$20 \mathrm{kDa}$

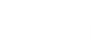

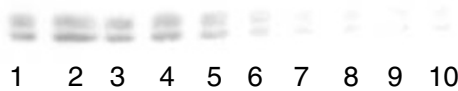

B

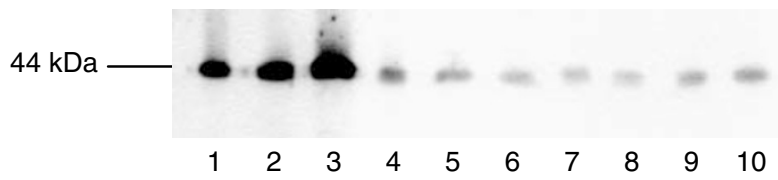

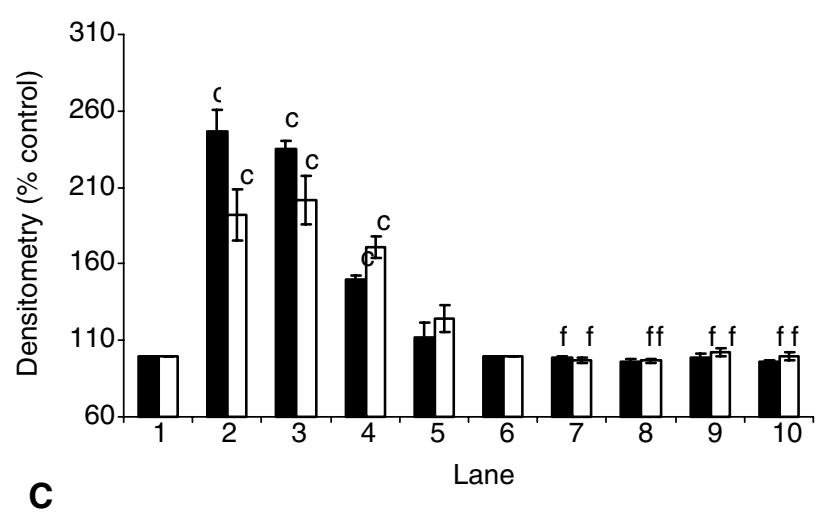

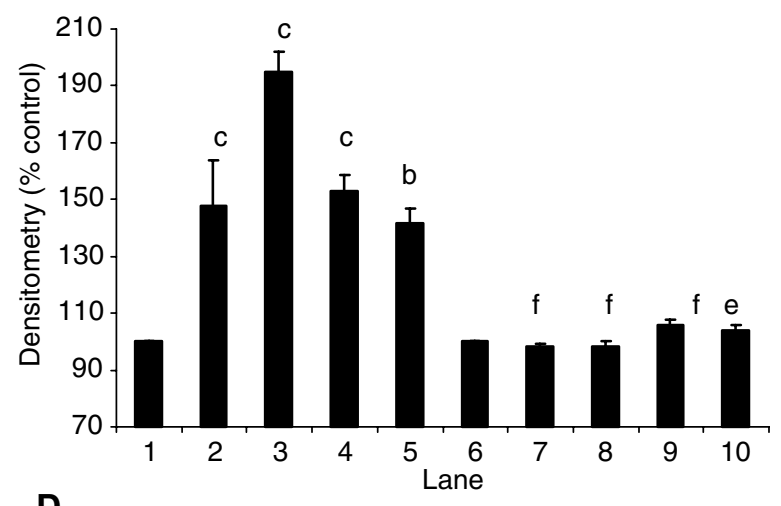

D
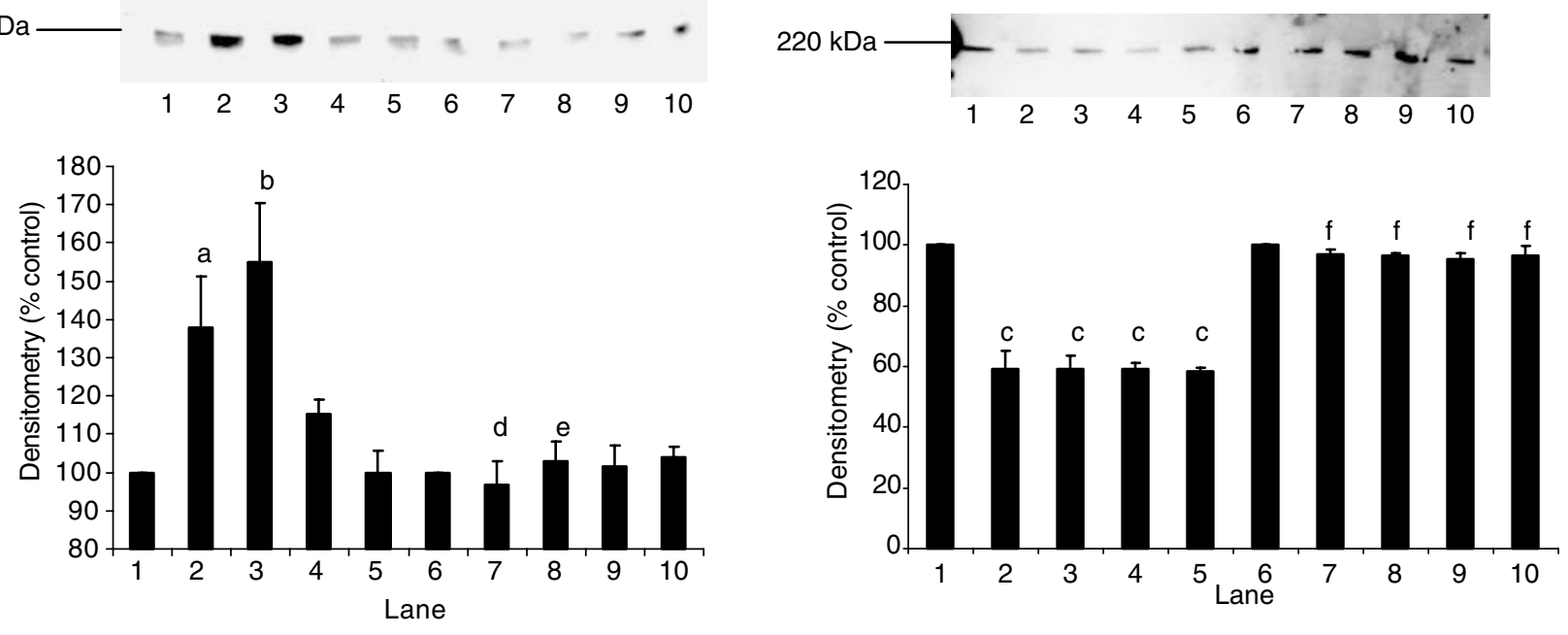

E

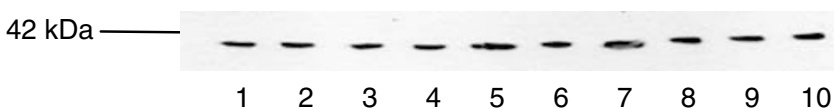

Figure 6 Effect of resveratrol on PIF-induced expression of 205 proteasome $\alpha$-subunits (A), p42 (B), MSSI (C) and myosin (D) as determined by Western blotting. An actin loading control is shown in (E). Cells were incubated with 0 (lanes I and 6), 2.I (lanes 2 and 7), 4.2 (lanes 3 and 8 ), I0.5 (lanes 4 and 9) or $16.8 \mathrm{nM}$ PIF (lanes 5 and I0) in the absence (lanes I-5) or presence (lanes $6-10$ ) of resveratrol (30 $\mu \mathrm{M}$ ) for $24 \mathrm{~h}$. A densitometric analysis of the three separate Western blots is shown underneath a representative example. Differences from control are indicated as $a, P<0.05, b, P<0.01$ and $c$, $P<0.00 \mathrm{I}$, while differences in the presence of resveratrol are indicated as $\mathrm{d}, P<0.05, \mathrm{e}, P<0.0 \mathrm{I}$ and $\mathrm{f}, P<0.00 \mathrm{I}$.

inhibitor lactacystin $(10 \mu \mathrm{M})$. Only lactacystin suppressible activity was considered to be proteasome specific.

\section{Western blot analysis}

Myotubes were incubated with various concentrations of PIF as depicted in the figure legends, after which the medium was removed and the cells were washed with $\mathrm{PBS}$ and scraped from the plastic surface. They were then sonicated at $4{ }^{\circ} \mathrm{C}$ in $500-2000 \mu \mathrm{l}$ of $20 \mathrm{~mm}$ Tris- $\mathrm{HCl}$, pH 7.5, $2 \mathrm{~mm} \mathrm{ATP,} 5 \mathrm{~mm} \mathrm{MgCl}_{2}$ and $1 \mathrm{~mm}$ DTT. Samples of cytosolic protein $(5-30 \mu \mathrm{g})$, formed by centrifugation at $18000 \mathrm{~g}$ for $5 \mathrm{~min}$, were resolved on $12 \%$ sodium dodecylsulphate, polyacrylamide gels (SDS/PAGE) and transferred to $0.45 \mu \mathrm{m}$ nitrocellulose membranes, which had been blocked with $5 \%$

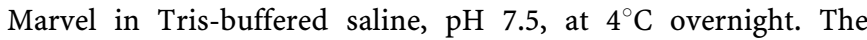
primary antibodies were used at a dilution of $1: 1000$ except for actin $(1: 200)$ and myosin $(1: 100)$, and the secondary antibodies were also used at a dilution of $1: 1000$. Incubation was for $1 \mathrm{~h}$ at room temperature and development was by enhanced chemiluminescence (ECL) (Amersham, United Kingdom). Blots were scanned by a densitometer to quantitate differences.

\section{Electrophoresis mobility shift assay}

DNA-binding proteins were extracted from myotubes according to the method of Andrews and Faller (1991), which utilises hypotonic 

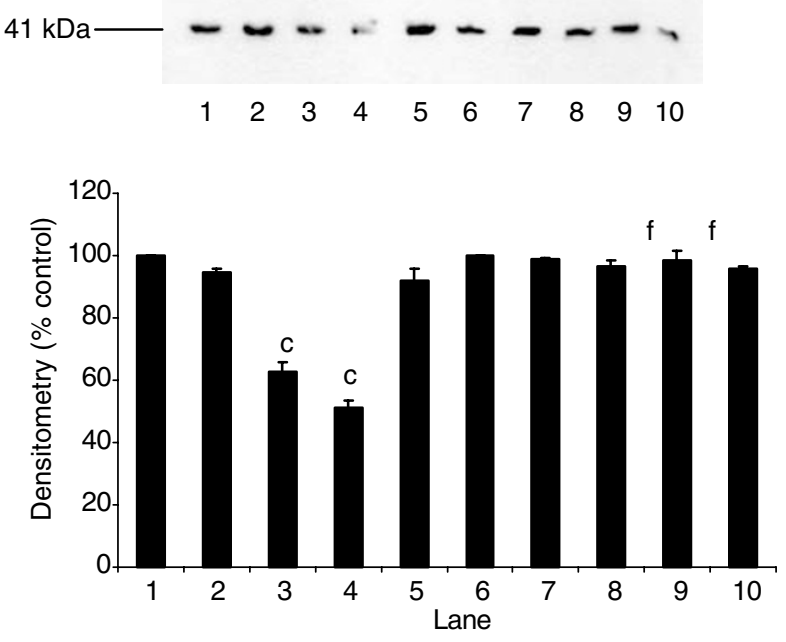

B
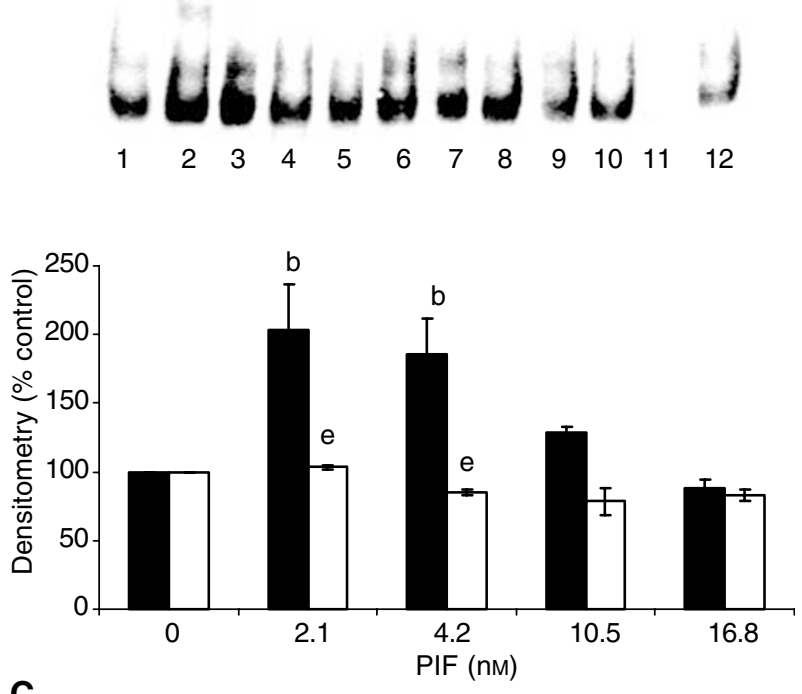

C

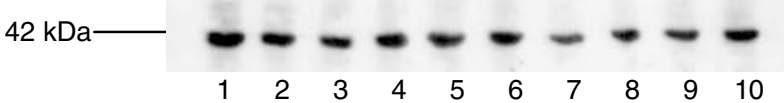

Figure 7 Effect of PIF on $1-\kappa \mathrm{B} \alpha$ expression $(\mathbf{A})$ and nuclear translocation of NF- $\kappa \mathrm{B}$, as determined by EMSA (B) in murine myotubes $30 \mathrm{~min}$ after the addition of PIF. An actin loading control for $(\mathbf{A})$ is shown in $(\mathbf{C})$. Myotubes were incubated with 0 (lanes I and 6), 2.I (lanes 2 and 7), 4.2 (lanes 3 and 8), 10.5 (lanes 4 and 9) or 16.8 nM PIF (lanes 5 and 10) in the absence (lanes I-5) or presence (lanes 6-10) of resveratrol $(30 \mu \mathrm{M})$. In (B), lane 12 is a positive control for NF- $\kappa \mathrm{B}$ (supplied by the manufacturer of the kit), while lane I I contains the positive control for NF- $\kappa \mathrm{B}$ together with a 100 -fold excess of unlabelled NF- $\kappa$ B probe. The densitometric analysis represents three separate experiments. Differences from control are indicated as $b, P<0.01$ and $c, P<0.001$, while differences in the presence of resveratrol are indicated as e, $P<0.01$ and $f, P<0.001$.

lysis followed by high salt extraction of nuclei. The EMSA-binding assay was carried out using a Panomics EMSA 'gel shift' kit according to the manufacturer's instructions.

\section{Statistical analysis}

Differences in means between groups was determined by one-way ANOVA, followed by Tukey's post-test.

\section{RESULTS}

To investigate the importance of activation of NF- $\kappa \mathrm{B}$ in PIFinduced proteasome expression and degradation of myofibrillar proteins in murine myotubes, the cell permeable specific NF- $\kappa \mathrm{B}$ inhibitor SN50 $(18 \mu \mathrm{M})$ was used to block agonist-induced nuclear translocation of NF- $\kappa \mathrm{B}$ (Lin et al, 1995). At this concentration, SN50 is not cytotoxic, and there have been no reports that it interferes with any other signalling pathway. The PIF-induced increase in 20S proteasome $\alpha$-subunits seen in the presence of the inactive congener was not seen in the presence of SN50 (Figure 1A). Similar results were seen for PIF-induced stimulation of MSS1, an ATPase subunit of the $19 \mathrm{~S}$ regulatory complex (Figure 1B), p42, an ATPase subunit of the $19 \mathrm{~S}$ regulator that promotes ATP-dependent association of the $20 \mathrm{~S}$ proteasome with the $19 \mathrm{~S}$ regulator to form the $26 \mathrm{~S}$ proteasome (Tanahashi et al, 1999) (Figure 1C), and E2 ${ }_{14 \mathrm{k}}$, one of the major mammalian E2s that support E3 $\alpha$-dependent ubiquitin conjugate formation (Attaix et al, 1999) (Figure 1D), as well as the PIF-induced decrease in myosin expression (Figure 1E). In each case, PIF produced an effect between 2.1 and $10.5 \mathrm{nM}$, which was not seen in the presence of SN50. These results suggest that nuclear translocation of NF- $\kappa \mathrm{B}$ is essential for PIF-induced proteasome expression, ubiquitin conjugation and loss of the myofibrillar protein myosin.

To evaluate the effect of pharmacological inhibition of NF- $\kappa \mathrm{B}$ on PIF-induced proteasome expression and protein degradation, the IKK inhibitor curcumin (Thaloor et al, 1999) was employed. At a concentration of $50 \mu \mathrm{M}$, curcumin completely attenuated total protein degradation in murine myotubes at all concentrations of PIF (Figure 2A). In addition, curcumin attenuated the PIF-induced increase in 'chymotrypsin-like' enzyme activity (Figure 2B), the predominant proteolytic activity of the proteasome, as well as the increase in $20 \mathrm{~S}$ proteasome $\alpha$-subunits and E2 $2_{14 \mathrm{k}}$ (Figure 3). These results suggest that curcumin may be effective in the treatment of muscle atrophy in cancer cachexia. However, when curcumin was evaluated in vivo in mice bearing the MAC16 tumour, it was shown to be ineffective in preventing loss of body weight at dose levels of 150 and $300 \mathrm{mg} \mathrm{kg}^{-1}$ (Figure 4). These results prompted us to look for alternative inhibitors of NF- $\kappa \mathrm{B}$, which may be effective in vivo.

Thus, the effect of another inhibitor of IKK, resveratrol (Holmes-McNary and Baldwin, 2000) on PIF-induced protein degradation and proteasome expression was studied in murine myotubes. At a concentration of $30 \mu \mathrm{M}$, resveratrol effectively attenuated both PIF-induced protein degradation (Figure 5A), as well as the proteasome chymotrypsin-like enzyme activity (Figure 5B). Resveratrol also attenuated the PIF-induced increase in $20 \mathrm{~S}$ proteasome $\alpha$-subunit expression (Figure 6A), p42 (Figure 6B), MSS1 (Figure 6C), as well as the decrease in myosin expression produced by PIF (Figure 6D). To confirm that resveratrol produced effects on NF- $\kappa \mathrm{B}$ at this concentration, murine myotubes were treated with resveratrol $(30 \mu \mathrm{M}) 2 \mathrm{~h}$ prior to the addition of PIF and the effect on I- $\kappa \mathrm{B} \alpha$ degradation and nuclear accumulation of NF- $\kappa \mathrm{B}$ was determined (Figure 7). Both PIFinduced degradation of $\mathrm{I}-\kappa \mathrm{B} \alpha$ (Figure $7 \mathrm{~A}$ ), and nuclear binding of NF- $\kappa \mathrm{B}$ in response to PIF (Figure $7 \mathrm{~B}$ ) were effectively inhibited by resveratrol, confirming that the mechanism of action in murine myotubes was as expected.

To evaluate the anticachectic effect of resveratrol, mice bearing the MAC16 tumour, and with established weight loss (5\%) were treated with resveratrol $\left(1 \mathrm{mg} \mathrm{kg}^{-1}\right)$ daily and the effect on body weight and tumour volume were determined (Figure 8 ). Resveratrol significantly attenuated weight loss within $24 \mathrm{~h}$ of administration (Figure 8A) and this was accompanied by inhibition of tumour growth within $48 \mathrm{~h}$ (Figure 6B). In order to determine whether the increase in body weight in mice treated with resveratrol resulted from a reduction in protein degradation, the rate of protein degradation in soleus muscle was determined by the release of tyrosine (Figure 9). Previous studies (Beck et al, 1991) 
A

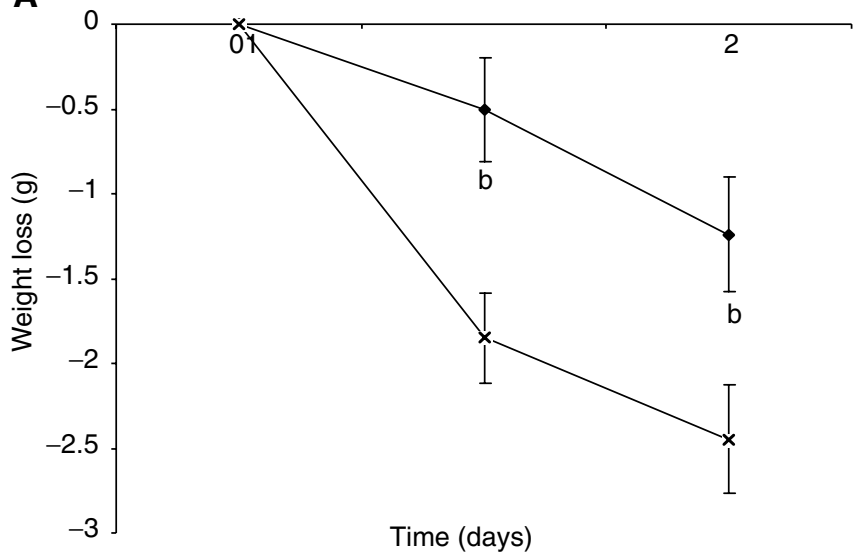

B

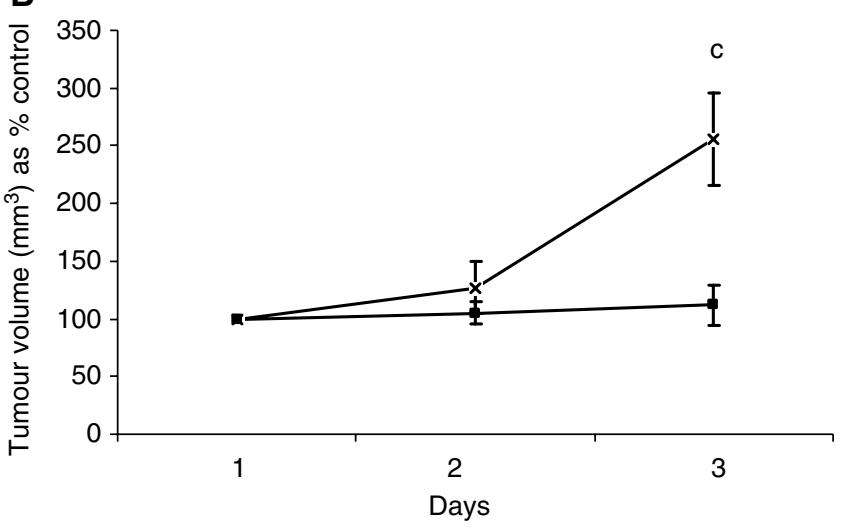

Figure 8 Effect of resveratrol $\left(1 \mathrm{mg} \mathrm{kg}^{-1} \boldsymbol{\nabla}\right)$ on body weight $(\mathbf{A})$ and tumour volume $(\mathbf{B})$ in mice bearing the $\mathrm{MACl} 6$ colon adenocarcinoma compared with solvent (DMSO:PBS; $1: 20$ ) controls $(x)$. The number of mice in each group, $n=6$. Differences from control are indicated $a s b$, $P<0.01$ and $c, P<0.001$.

have shown that muscles from mice bearing the MAC16 tumour have a significant increase in protein degradation compared with nontumour-bearing controls. Soleus muscle of mice bearing the MAC16 tumour and treated with resveratrol had a significant reduction in protein degradation after $48 \mathrm{~h}$ treatment compared to muscles from mice treated with solvent alone (from $955 \pm 125$ to $568 \pm 4.5$ fluorescent units $\left.\mathrm{g}^{-1} 2 \mathrm{~h}^{-1}, P<0.001, n=12\right)$. To verify that this arose from an effect on nuclear migration of NF- $\kappa \mathrm{B}$, the amount of NF- $\kappa \mathrm{B}$ in the nucleus was determined by EMSA. The results depicted in Figure 9 show a significant reduction in NF- $\kappa$ B DNA-binding activity in gastrocnemius muscles of mice treated with resveratrol. These results suggest that agents which inhibit nuclear translocation of NF- $\kappa$ B may prove useful in the treatment of muscle wasting in cancer cachexia.

\section{DISCUSSION}

Nuclear factor $-\kappa \mathrm{B}$ is involved in the control of a large number of cellular processes, such as immune and inflammatory responses, developmental processes, cell growth and apoptosis (Baldwin, 1996). Activation of NF- $\kappa$ B has been connected with tumour cell survival and proliferation, invasion and angiogenesis, critical events in tumour metastasis, as well as resistance to chemotherapy (Baldwin, 2001). Nuclear factor- $\kappa \mathrm{B}$ has also been shown to mediate the protein loss induced by tumour necrosis factor- $\alpha$ (TNF- $\alpha$ ) in differentiated skeletal muscle myotubes (Li and Reid, 2000), and to

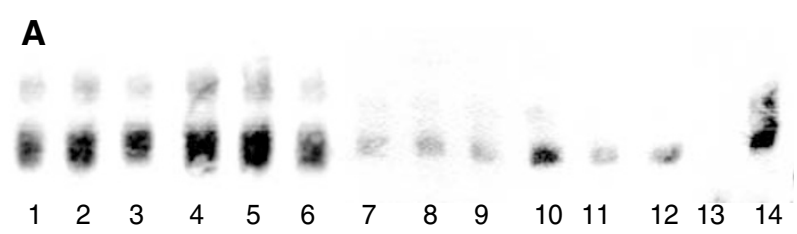

B

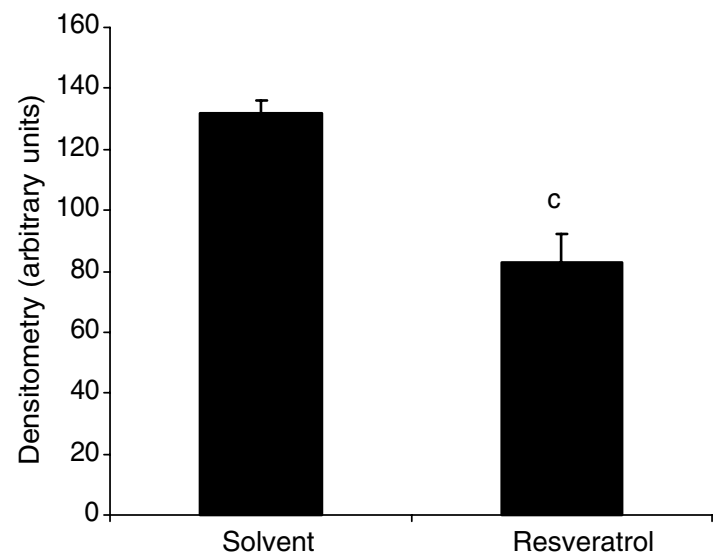

Figure 9 (A) EMSA of nuclear binding of NF- $\kappa \mathrm{B}$ in gastrocnemius muscle of mice receiving solvent control (lanes 1-6) or resveratrol $\left(\mathrm{l} \mathrm{mg} \mathrm{kg}{ }^{-1}\right.$ ) (lanes 7- 12 ) after $48 \mathrm{~h}$ treatment. Lane 14 is the positive control for NF- $\kappa \mathrm{B}$ and lane $\mathrm{I} 3$ is the positive control in the presence of a 100 -fold excess of unlabelled NF- $\kappa$ B probe. (B) Densitometric analysis of the EMSA shown in $(\mathbf{A}), n=3$. Differences from control are shown as $c$, $P<0.001$.

be an important transcription factor in PIF-induced proteasome expression in murine myotubes (Whitehouse and Tisdale, 2003). Nuclear factor $-\kappa \mathrm{B}$ may also be involved in other conditions of muscle wasting. Thus, hind-limb unloading, a model of disuse atrophy, resulted in a 10-fold increase in the activity of a transfected NF- $\kappa \mathrm{B}$-dependent reporter (Hunter et al, 2002), but this involved p50, c-Rel and Bcl-3 and not activation of p65 or $\mathrm{I}-\kappa \mathrm{B}$, and is thus distinct from cachexia.

This suggests that inhibitors of the release and subsequent nuclear translocation of NF- $\kappa \mathrm{B}$, or the binding of NF- $\kappa \mathrm{B}$ to DNA should be evaluated as potential agents to prevent muscle atrophy in cancer cachexia. Agonist-induced nuclear translocation of $\mathrm{NF}-\kappa \mathrm{B}$ in intact cells can be inhibited by cell-permeable synthetic peptides representing the nuclear localisation sequence of NF- $\kappa \mathrm{B}$ (Lin et al, 1995). When such a peptide (SN50) was incubated together with PIF in murine myotubes it attenuated both the PIFinduced proteasome expression and the ubiquitin conjugating enzyme, $\mathrm{E} 2_{14 \mathrm{k}}$, as well as the loss of myofibrillar protein myosin. These results suggest that inhibition of NF- $\kappa \mathrm{B}$ activation should inhibit muscle protein degradation induced by PIF in cancer cachexia.

Both curcumin and resveratrol, known to be inhibitors of IKK, attenuated PIF-induced protein degradation in murine myotubes, as well as the increased expression of the ubiquitin-proteasome proteolytic pathway. Systemic administration of curcumin $\left(20 \mu \mathrm{g} \mathrm{kg}^{-1}\right)$ has previously been shown not to influence muscle wasting or changes in body weight in rats bearing the highly cachectic Yoshida AH-130 ascites hepatoma, although it did reduce tumour growth (Busquets et al, 2001). In the present study, curcumin was also unable to reduce weight loss in mice bearing the MAC16 tumour, even at much higher doses (150 and $300 \mathrm{mg} \mathrm{kg}^{-1}$ ). This may be due to the low bioavailability ( $0.06 \%$ absorption) (Pan et al, 1999), which is probably insufficient to exert a therapeutic effect. Even a dose of $1 \mathrm{~g} \mathrm{~kg}^{-1}$ body weight in the mouse yielded a 
plasma level of only $0.5 \mu \mathrm{M}$ (Pan et al, 1999), which is below the concentration needed to attenuate PIF action in vitro. Resveratrol $\left(1 \mathrm{mg} \mathrm{kg}^{-1}\right)$ was also unable to prevent the loss of body weight in rats bearing the Yoshida hepatoma, although again it did reduce tumour growth rate (Carbó et al, 1999). In this study, resveratrol at the same concentration $\left(1 \mathrm{mg} \mathrm{kg}^{-1}\right)$ was found to attenuate weight loss, followed by a reduction in tumour growth rate in mice bearing the MAC16 tumour, reduce protein degradation in skeletal muscle, as determined by the release of tyrosine, and reduce nuclear translocation of NF- $\kappa \mathrm{B}$ in gastrocnemius muscle. The reason for the difference in response to resveratrol in the two models is not clear. Although TNF- $\alpha$ has been implicated in the enhanced protein degradation in muscle of rats bearing the Yoshida ascites hepatoma (Costelli et al, 1993), while in mice bearing the MAC16 carcinoma PIF appears to be responsible for the enhanced protein degradation (Lorite et al, 1998), NF- $\kappa \mathrm{B}$ has been shown to mediate the protein loss induced by TNF- $\alpha$ (Li and Reid, 2000) and thus inhibitors of NF- $\kappa$ B should also be effective in this model.

Other inhibitors of NF- $\kappa$ B have established or potential roles in the treatment of cachexia. Thus EPA, which prevents nuclear migration of NF- $\kappa \mathrm{B}$ in murine myotubes in response to PIF by stabilising the cytosolic I- $\kappa \mathrm{B} / \mathrm{NF}-\kappa \mathrm{B}$ complex (Whitehouse and Tisdale, 2003), possibly by interfering with $\mathrm{I}-\kappa \mathrm{B}$ phosphorylation (Novak et al, 2003), has been shown to attenuate the development of further weight loss in weight-losing patients with pancreatic cancer (Wigmore et al, 2000) and produce an increase in lean body mass when combined with a high protein energy dense nutritional supplement (Barber et al, 1999). The anti-inflammatory agent, ibuprofen, has been shown to inhibit constitutive activation of NF$\kappa \mathrm{B}$ and IKK $\alpha$ in prostate cancer cells (Palayoor et al, 1999), and when combined with megestrol acetate produced an increase in body weight in gastrointestinal cancer patients (McMillan et al, 1999), while megestrol acetate alone produced a decrease in body weight. Another anti-inflammatory agent, thalidomide, can also block NF- $\kappa$ B activation through inhibition of IKK (Keifer et al, 2001), and has been shown to promote weight gain in HIV-infected patients receiving treatment for tuberculosis (Reys-Teran et al, 1996), and is currently under evaluation for the treatment of cancer cachexia. These results suggest that despite the fact that NF- $\kappa \mathrm{B}$ is involved in the control of over 150 target genes (Pahl, 1999), inhibitors of NF- $\kappa$ B activation do not produce overt toxicity and should be evaluated for the treatment of muscle atrophy in cancer cachexia.

\section{REFERENCES}

Andrews NC, Faller DV (1991) A rapid micropreparation technique for extraction of DNA-binding proteins from limiting numbers of mammalian cells. Nucleic Acids Res 19: 2499

Attaix D, Combaret L, Tilignac T, Taillandier D (1999) Adaption of the ubiquitin - proteasome proteolytic pathway in cancer cachexia. Mol Biol Rep 26: $77-82$

Baldwin AS (1996) The NF- $\kappa \mathrm{B}$ and $\mathrm{I} \kappa \mathrm{B}$ proteins: new discoveries and insights. Ann Rev Immunol 14: 649-681

Baldwin AS (2001) Control of oncogenesis and cancer therapy resistance by the transcription factor NF- $\kappa$ B. J Clin Invest 107: $241-246$

Barber MD, Ross JA, Voss AC, Tisdale MJ, Fearon KCH (1999) The effect of an oral nutritional supplement enriched with fish oil on weight-loss in patients with pancreatic cancer. Br J Cancer 81: 80-86

Beck SA, Smith KL, Tisdale MJ (1991) Anticachectic and antitumor effect of eicosapentaenoic acid and its effect on protein turnover. Cancer Res 51: 6089-6093

Beck SA, Tisdale MJ (1987) Production of lipolytic and proteolytic factors by a murine tumor-producing cachexia in the host. Cancer Res 47: $5919-5923$

Bossola M, Muscaritoli M, Costelli P, Grieco G, Bonelli G, Pacelli F, Fanelli FR, Doglietto GB, Baccino FM (2003) Increased muscle proteasome activity correlates with disease severity in gastric cancer patients. Ann Surg 237: $384-389$

Brockman JA, Scherer DC, McKinsey TA, Hall SM, Qi X, Lee WY, Ballard DW (1993) Coupling of a signal response domain in I- $\kappa \mathrm{B} \alpha$ to multiple pathways for NF- $\kappa \mathrm{B}$ activation. Mol Cell Biol 15: $2809-2818$

Busquets S, Carbo N, Almendro V, Quiles MT, Lopez-Soriano FJ, Argiles JM (2001) Curcumin, a natural product in turmeric, decreases tumor growth but does not behave as an anticachectic compound in a rat model. Cancer Lett 167: 33-38

Carbó N, Costelli P, Baccino FM, Lopez-Soriano FJ, Argiles JM (1999) Resveratrol, a natural product present in wine, decreases tumour growth in a rat tumour model. Biochem Biophys Res Commun 254: $739-743$

Costelli P, Carbo N, Tessitore L, Bagby GJ, Lopez-Soriano FJ, Argiles JM, Baccino FM (1993) Tumor necrosis factor-alpha mediates changes in tissue protein turnover in a rat cancer cachexia model. J Clin Invest 92: $2783-2789$

Holmes-McNary M, Baldwin Jr AS (2000) Chemopreventative properties of trans-resveratrol are associated with inhibition of activation of $\mathrm{I} \kappa \mathrm{B}$ kinase. Cancer Res 60: 3477-3483

Hunter RB, Stevenson EJ, Koncarevic A, Mitchell-Fenton H, Essig DA, Kandarin SC (2002) Activation of an alternative NF- $\kappa$ B pathway in skeletal muscle during disuse atrophy. FASEB J 16: 529-539
Keifer JA, Guttridge DC, Ashburner BP, Baldwin Jr AS (2001) Inhibition of NF- $\kappa \mathrm{B}$ activity by thalidomide through suppression of $\mathrm{I} \kappa \mathrm{B}$ kinase activity. J Biol Chem 276: 22382-22387

Li Y-P, Reid MB (2000) NF- $\kappa$ B mediates the protein loss induced by TNF- $\alpha$ in differentiated skeletal muscle myotubes. Am J Physiol 279: R1165 - R1170

Lin YZ, Yao SY, Veach RA, Torgerson TR, Hawiger J (1995) Inhibition of nuclear translocation of transcription factor NF-kappaB by a synthetic peptide containing a cell membrane-permeable motif and nuclear localization sequence. $J$ Biol Chem 270: $14255-14258$

Lorite MJ, Cariuk P, Tisdale MJ (1997) Induction of muscle protein degradation by a tumour factor. Br J Cancer 76: $1035-1040$

Lorite MJ, Smith HJ, Arnold JA, Morris A, Thomspon MG, Tisdale MJ (2001) Activation of ATP-ubiquitin-dependent proteolysis in skeletal muscle in vivo and murine myoblasts in vitro by a proteolysis-inducing factor (PIF). Br J Cancer 85: 297-302

Lorite MJ, Thompson MG, Drake JL, Carling G, Tisdale MJ (1998) Mechanism of muscle protein degradation induced by a cancer cachectic factor. Br J Cancer 78: 850-856

McMillan DC, Wigmore SJ, Fearon KCH, O'Gorman P, Wright CE, McArdle CS (1999) A prospective randomized study of megestrol acetate and ibuprofen in gastrointestinal patients with weight loss. Br J Cancer 79: $495-500$

Novak TE, Babcock TE, Jho DH, Helton WS, Espat NJ (2003) NF- $\kappa$ B inhibition by $\omega-3$ fatty acids modulates LPS-stimulated macrophage TNF- $\alpha$ transcription. Am J Physiol 284: L84-L89

Orino E, Tanaka K, Tamura T, Sone S, Ogura T, Ichihara A (1991) ATPdependent reversible association of proteasomes with multiple protein components to form $26 \mathrm{~S}$ complexes that degrade ubiquitinated proteins in human HL-60 cells. FEBS Lett 284: 206-210

Pahl HL (1999) Activators and target genes of Rel/NF- $\kappa$ B transcription factors. Oncogene 18: 6853-6866

Palayoor ST, Youmell MY, Calderwood SK, Coleman CN, Price BD (1999) Constitutive activation of $\mathrm{I} \kappa \mathrm{B}$ kinase $\alpha$ and NF- $\kappa \mathrm{B}$ in prostate cancer cells is inhibited by ibuprofen. Oncogene 18: 7389-7394

Pan MH, Huang TM, Lin JK (1999) Biotransformation of curcumin through reduction and glucuronidation in mice. Drug Metab Dispos 27: $486-494$

Reys-Teran G, Sierra-Madero JG, Martinez del Cerro V, Figueroa H, Pasquertti A, Calva JJ, Ruiz-Pabcious GM (1996) Effects of thalidomide on HIV-associated wasting syndrome: a randomized, double-blind, placebo controlled trial. AIDS 10: 1501-1507

Smith HJ, Wyke SM, Tisdale MJ (2004) Role of protein kinase C and NF- $\kappa \mathrm{B}$ in proteolysis-inducing factor induced proteasome expression in $\mathrm{C}_{2} \mathrm{C}_{12}$ myotubes. Br J Cancer 90: 1850-1857 
Tanahashi N, Kawahara H, Murakami Y, Tanaka K (1999) The proteasomedependent proteolytic system. Mol Biol Rep 26: 3-9

Thaloor D, Miller KJ, Gephart J, Mitchell PO, Pavlath GK (1999) Systemic administration of the NF- $\kappa \mathrm{B}$ inhibitor curcumin stimulates muscle regeneration after traumatic injury. Am J Physiol 277: C320-C329

Todorov P, Cariuk P, McDevitt T, Coles B, Fearon K, Tisdale M (1996a) Characterization of a cancer cachectic factor. Nature 379: $739-742$

Todorov PT, McDevitt TM, Cariuk P, Coles B, Deacon M, Tisdale MJ (1996b) Induction of muscle protein degradation and weight loss by a tumor product. Cancer Res 56: $1256-1261$

Waalkes TP, Udenfriend SA (1957) A fluorimetric method for the estimation of tyrosine in plasma and tissues. J Lab Clin Med 50: $733-736$
Whitehouse AS, Smith HJ, Drake JL, Tisdale MJ (2001) Mechanism of attenuation of skeletal muscle protein catabolism in cancer cachexia by eicosapentaenoic acid. Cancer Res 61: 3604-3609

Whitehouse AS, Tisdale MJ (2003) Increased expression of the ubiquitin proteasome pathway in murine myotubes by proteolysis-inducing factor (PIF) is associated with activation of the transcription factor NF- $\kappa \mathrm{B} . \mathrm{Br} J$ Cancer 89: $1116-1122$

Wigmore SJ, Barber MD, Ross JA, Tisdale MJ, Fearon KCH (2000) Effect of oral eicosapentaenoic acid on weight loss in patients with pancreatic cancer. Nutr Cancer 36: 177-184

Workman P, Twentyman P, Balkwill F, Balmain A, Chaplin D, Double J, Embelton J, Newell D, Raymond R, Stables J, Stephens T, Wallace J (1998) United Kingdom Co-ordinating Committee on Cancer Research (UKCCR). Guidelines for the welfare of animals with experimental neoplasia (second edition). Br J Cancer 77: 1-10 